\title{
Music consumption in Brazil: an analysis of streaming reproductions
}

DOI: https://doi.org/10.22409/pragmatizes.v10i19.40565

\author{
Gabriel Borges Vaz de Melo' \\ Ana Flavia Machado ${ }^{2}$ \\ Lucas Resende de Carvalho ${ }^{3}$
}

\begin{abstract}
Music is one of the cultural segments that most adapts and innovates, as observed in the recent rise of streaming services. The consumption of digital music has altered the dynamics of the market and the way people enjoy it. The aim of this article is to show trends and tastes of Brazilian individuals, taking into account musical genres. For this purpose, it uses data of playlists collected from the Spotify streaming platform through its API. The results show that genres such as sertanejo universitário and international pop have great national reach. However, other national genres and artists with less popularity have a relevant and distinct demand in some Brazilian cities. Our analysis indicates both the maintenance of the traditional consumption as the rise of the mass-replacement model. Therefore, a regionalization of the musical taste in Brazil is evidenced,which suggests a potential of musical niches in the context of the streaming market.
\end{abstract}

Keywords: consumption; music; genre; streaming

\section{Consumo de música no Brasil: uma análise de reproduções de streaming}

Resumo: A música é um dos segmentos culturais que mais se adapta e inova, tal como observa-se na recente ascensão dos serviços de streaming. O objetivo deste artigo é mostrar tendências e gostos dos indivíduos, levando em consideração os gêneros musicais. Para tal, foram utilizados dados da plataforma Spotify. Os resultados apontam que gêneros como sertanejo universitário e pop internacional possuem grande alcance nacional. Porém, outros gêneros nacionais possuem uma demanda relevante e distinta em algumas cidades brasileiras. Evidencia-se, portanto, uma regionalização do gosto musical no Brasil, o que sugere um potencial de nichos musicais quando inseridos no contexto do mercado de streaming.

Palavras-chave: consumo; música; gênero; streaming

\footnotetext{
${ }^{1}$ Gabriel Borges Vaz de Melo. Mestre em Economia pela Universidade Federal de Minas Gerais (UFMG), Brasil. E-mail: gabrielvazdemelo@gmail.com - https://orcid.org/0000-0002-3323-8635

${ }^{2}$ Ana Flavia Machado. Doutora em Economia pela Universidade Federal do Rio de Janeiro, professora da Universidade Federal de Minas Gerais, Brasil. E-mail: afmachad@cedeplar.ufmg.br https://orcid.org/0000-0001-8573-7906

${ }^{3}$ Lucas Resende de Carvalho. Doutorando do Programa de Pós-Graduação em Economia da Universidade Federal de Minas Gerais/UFMG e bolsista da CAPES, Brasil. E-mail: lucasrc@cedeplar.ufmg.br - https://orcid.org/0000-0002-3618-3967
} 
Consumo de música en Brasil: un análisis de reproducciones en streaming

Resumen: La música es uno de los segmentos culturales que más se adapta y innova, tal como se observa en la reciente ascensión de los servicios de streaming. El objetivo de este artículo es mostrar tendencias y gustos de los individuos, teniendo en cuenta los géneros musicales. Para esto, se utilizaron datos de la plataforma Spotify. Los resultados apuntan que géneros como sertanejo universitario y pop internacional poseen gran alcance nacional. Sin embargo, otros géneros nacionales poseen una demanda relevante y distinta en algunas ciudades brasileñas. Se evidencia, por lo tanto, una regionalización del gusto musical en Brasil, lo que sugiere un potencial de nichos musicales cuando se inserta en el contexto del mercado de streaming.

Palabras clave: consumo; musica; género; streaming

\section{Music consumption in Brazil: an analysis of streaming reproductions}

\section{Introduction}

Music is one of the most primitive forms of cultural expression. However, it wasn't until the twentieth century that it began to be marketed as a consumer good. Since then, the music market has become more and more dynamic and creative in terms of musicians' production and listeners' consumption (CVETKOVSKI, 2004; THROSBY, 2002). Throsby (2002) points out that there is a paradox in relation to music, precisely because of this dichotomy between the past, linked to cultural expression and creativity, and the present, associated with market ideologies and mass production.

Leyshon (2014) states that the history of music from the late 1990s is a good example of innovation and adaptability: sharing and downloading of files, the crisis in physical sales, and, more recently, the rise of streaming platforms and subscriptions. Those changes are directly associated with the technological innovations absorbed by the phonographic market.

Regarding digital services, especially streaming, Pró-Música Brasil (2017) points to significant changes in perspectives in the music market. One of these services, Spotify, launched in 2008, stood out for having quickly gained a significant part of the world market by offering features that personalize the experience of digital music enjoyment.

In this way, in the context of a limited database about cultural consumption in Brazil, the use of digital media and platforms is an opportunity for the studies of cultural economics and, more specifically, as it is intended 


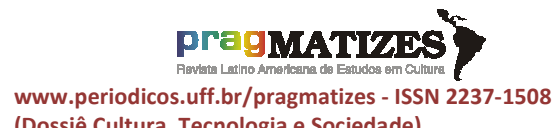

(Dossiê Cultura, Tecnologia e Sociedade) in this work, for the analysis of music consumption. Spotify, launched in Brazil in 2014, already has a relatively large and growing number of users. For this reason, it could be a good sample of digital consumption and its dimensions.

This paper aims, therefore, to map and analyze music consumption using reproduction data from Spotify in Brazil, considering the development of a specific algorithm to organize data collection of digital music. The analysis of the consumption behavior of the users contemplates genres and musical taste.

Besides this introduction and the final considerations, the paper is divided into three more sections. The first one presents a brief review of the literature related to effects of digitalization on cultural consumption. The subsequent section treats the methodological strategy. In the final part, the main observations and results are described.

Cultural consumption, taste, and music

Recent changes in consumption are directly associated with the new technologies and the virtual space in which the products have been inserted. According to Potts (2014), in traditional economic theory, technology and innovation are important variables and commonly analyzed in terms of production, but they are also important in consumption analysis.

Since the spread of file-sharing services in the 2000s, studies have examined the impact of digitalization on music consumption. Mainly related to "piracy", some of these studies attest to the negative effect on physical sales revenues (LIEBOWITZ, 2004). Others, however, question and propose alternative analyses (OBERHOLZER-GEE; STRUMPF, 2007). However, it is argued that it is practically impossible to adopt a favorable or contrary opinion, since the effect is quite dependent on other factors, as well as on the information used in each study (LIEBOWITZ, 2014).

Aguiar and Waldfogel (2016) show that, despite the fall in physical revenues, digitalization favors the quality of the musical product by allowing individuals to easily access new content in the market. Studies on Spotify specifically are even more scarce. Aguiar and Waldfogel (2015) 


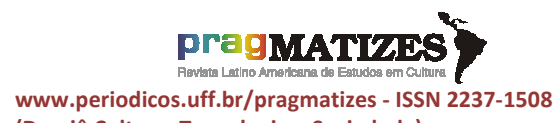

(Dossiê Cultura, Tecnologia e Sociedade) find evidence that the service reduces piracy and, in relation to sales, is relatively neutral.

Potts (2014) points out that one consequence of new technologies, such as streaming, in the cultural consumption would be an increase in variety and diversity of goods, which constitutes a form of market expansion, accompanied by low costs of insertion. This consequence is consistent with the hypothesis known as "Long Tail" proposed by Anderson (2006).

Anderson (2006) argues that digitalization has led to a drop in mass production and a shift in consumer preferences, especially as a consequence of the increase in the variety of products and in the media and entertainment market. In addition, the costs of storage of physical products are practically nullified, and distribution costs are reduced. According to Anderson (2006), technology converts mass production into millions of niches and thus reduces the concentration of the cultural goods market. Some markets, usually of monopolistic competition, including that of entertainment, present strong concentration in few actors, called the "superstars" effect (CAVES, 2006; ROSEN, 1981). The phonographic market could be a typical example where superstars and more popular artists are too few compared to a large number of smaller, independent artists. Digitalization, on the other hand, allows greater access to market niches where less popular artists are concentrated, ensuring that music previously obscured by the products of the big stars - "hits," according to Anderson (2006) - gain visibility and may have an effective demand.

In this way, the "non-hits" content of the niche markets becomes as relevant as the hits, in terms of both costs and profitability. Such equalization would be represented by the shape of a long tail distribution. Anderson (2006) argues that niches gain notoriety not only because they are available or visible, but also because consumers alter their preferences by having infinite choices provided by the digitalization.

Prey (2015) considers that the new streaming services represent "new spaces" of music consumption, where the objective is to regain control of digital music after Napster, reintegrating the listeners again in the 
environment of the music industry. In a sense, consumers are considered an active audience, since the behaviors and tastes of users on the streaming platforms serve as inputs and help the service itself in the development of its functions. For the author, Spotify is one of the services that has most developed and used these practices.

Considering this potential of Spotify, in the next section, we describe the methodology for capturing platform information to reach the goals proposed in this paper.

\section{Data mining: methodology description}

In the digital market, the emergence of Spotify is one of the most expressive in the streaming service, offering a relevant range of information. Given the possibility of extracting data, the main objective of this article is to map and analyze the consumption of music from data of reproductions of users in Brazil. Secondary goals run through how consumers have been changing their ways of using music when inserted into digital platforms. Among these are (i) analyzing the consumption behavior of users concerning musical genres, (ii) verifying the insertion of genres and international artists in the national scene, and (iii) ascertaining patterns of musical consumed taste with the main styles.

There are three steps to achieve these objectives. First, there are data collection and organization and, finally, analysis. It should be emphasized that it is not an objective of this work to create fixed definitions of musical styles, much less to elaborate judgments or to legitimize or devalue whatever gender, artist, or music.

The data collection process was started by reading and analyzing the routines made available by Spotify through its API, Spotify Web API (SPOTIFY, 2014). After explaining the available information, we proceeded to the elaboration of routines of programming and data collection ${ }^{4}$ of the most reproduced songs at the national level, as well as those that were distinctly or locally more popular in some cities. Both collections follow a similar logic of two-step division. In the Brazilian case, a first extraction of the

\footnotetext{
${ }^{4}$ Algorithms available in Author (2017).
} 
most played songs in Spotify Charts ${ }^{5}$ was made, followed by a search for additional information and respective artists and albums through Spotify Web API. It should be noted that the playlists have a total number of songs always equal to 200 , which is higher than the local playlists of the cities, which usually contain 100 . Besides, the Spotify Charts platform also offers the total streamings or reproductions of each track in the country, which is not possible in the extraction of cities.
The second extraction of the playlists of the cities was only possible because of their availability in the Every Place at Once ${ }^{6}$ project. Through the lists obtained in each municipality, consultations were made using Spotify Web API, achieving the same information about the songs, artists, and albums of the national collection. The collection period was extended from September 2016 to May 2017. Therefore, the variables of interest are listed:

\footnotetext{
${ }^{5}$ Available at: https://spotifycharts.com/regional/br/daily/latest . Access date: August 28, 2018.
} 
Table 1 - Selected variables

\begin{tabular}{|l|l|}
\hline Variables & Description \\
\hline Playlist & City's playlist name (e.g., The Sound of Sao Paulo BR) \\
\hline Number & $\begin{array}{l}\text { Position of the track in the playlist, according to the difference of the reproductions } \\
\text { in the city }\end{array}$ \\
\hline Artist & Artist name \\
\hline Track & Track name \\
\hline Preview & Link of a preview of 30 seconds of the track \\
\hline Pop_track & $\begin{array}{l}\text { Popularity of the track, ranging from } 0 \text { to 100, where } 100 \text { is the most popular } \\
\text { possible }\end{array}$ \\
\hline Markets & Countries where the track is available for playback \\
\hline Album & Name of the album that contains the track \\
\hline Pop_artist & Popularity of artist, ranging from 0 to 100, where 100 is the most popular possible \\
\hline Followers & Total artist followers \\
\hline Genre & Track genre \\
\hline Release date & Release date of the album in which the track is contained \\
\hline URI & Uniform resource identifier (URI) tags for artists, tracks, and albums \\
\hline
\end{tabular}

Source: SPOTIFY (2014).

\section{Music consumption described by playlists}

To achieve the purpose of this article, first, we analyzed the consumption of the most reproduced songs in Brazil, according to the playlists disposable in the domain
Spotify Charts. Figure 1 shows the different genres of the 200 songs most played by the users in November 2016. Pop genres - most of them international - and sertanejo universitário stand out. 


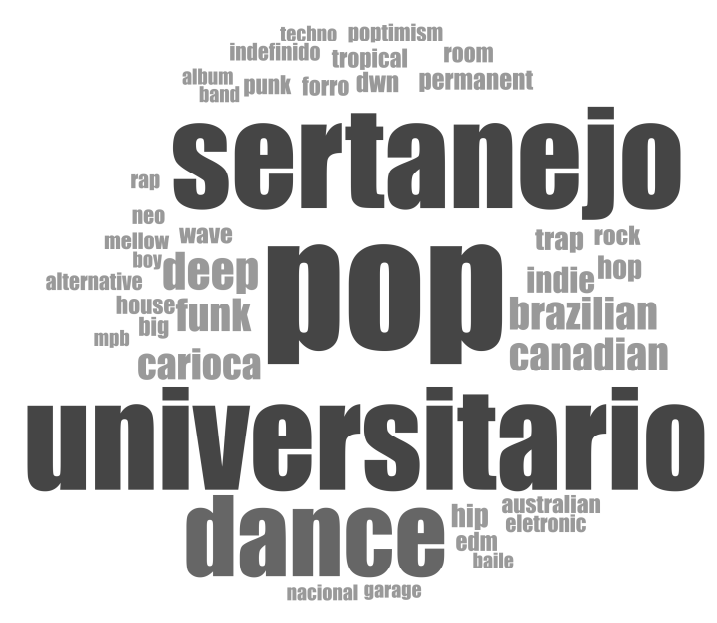

Fig. 1: Most heard genres, Brazil, November 2016. Source: SPOTIFY $(2014,2016)$.

This result resembles, in part, some studies in other countries. As Coulangeon and Lemel (2007, p. 98) point out, "music listening habits tend to focus mainly on the various genres of pop music, and, on average, the audiences for the other genres appear to be quite marginal." The American or English-speaking pop genre dominates much of the global market, while other local genres incorporate other market slices. In Brazil, much of the remaining market is absorbed by the genre sertanejo universitário, which has great marketing appeal and space in traditional media. However, Figure 1 presents other minor genres that are among the most played songs, indicating an expressive consumption of those as well. Subsequently, it was observed that these gender patterns differ for Brazilian cities. Figure 2 shows the same ranges, but distributed according to their position in the list and by gender classifications. 


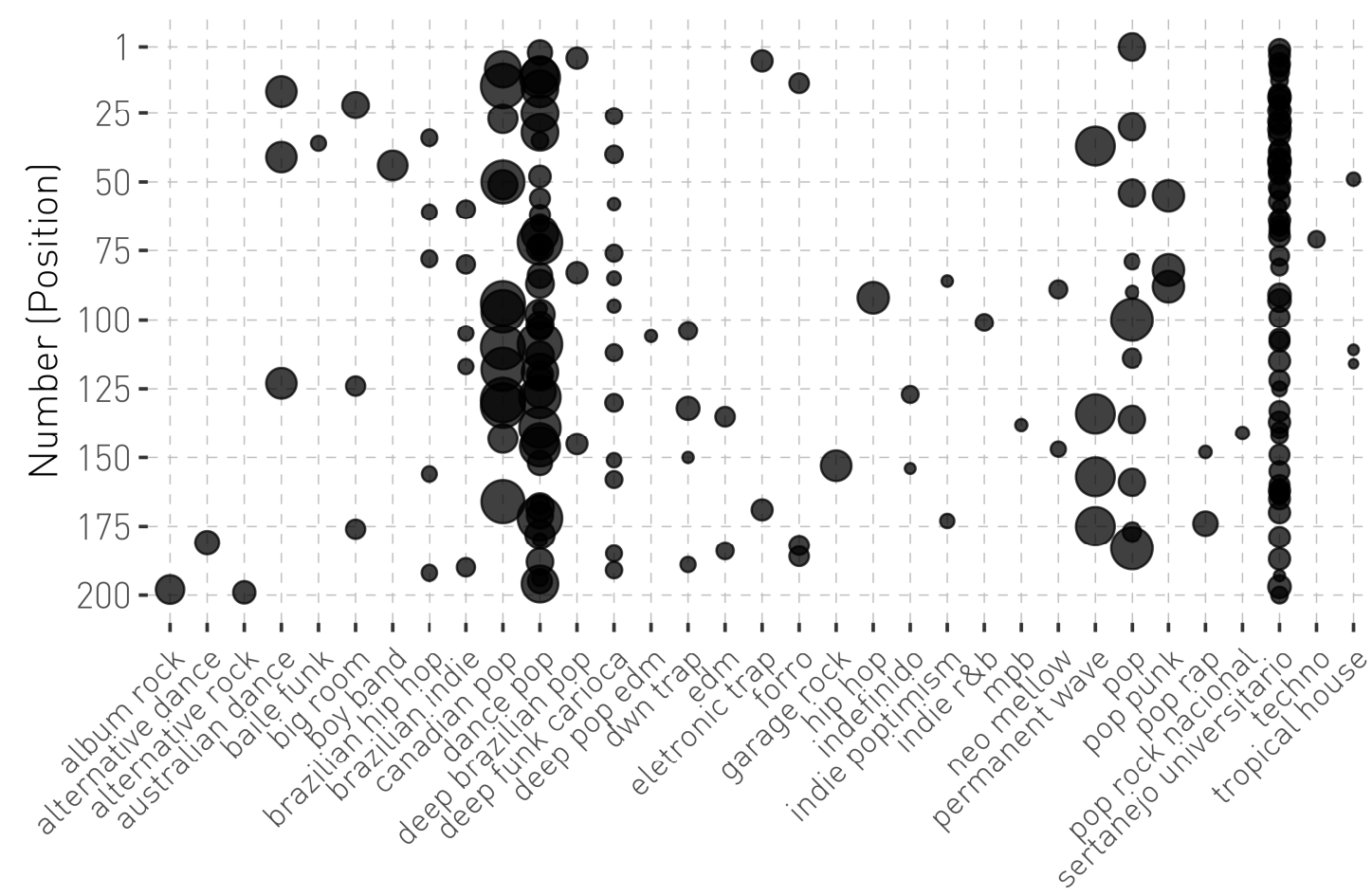

Genre

Followers $\bigcirc$ 2,500,000 5,000,000 7,500,000 10,000,000

Fig. 2: Songs' positions, Brazil, November 2016. Source: SPOTIFY $(2014,2016)$.

This suggests the prominence of the aforementioned genres. ${ }^{7}$ Songs of the pop and sertanejo universitário genres are present in practically the whole playlist, and the difference in the amount of followers of the artists of each genre in the international genres is evident. Clearly, this number is far superior to sertanejo. It is worth noting the low presence of bands compared to sertanejo - of other

\footnotetext{
${ }^{7}$ The pop genre includes three categories: Canadian pop, dance pop, and pop.
}

national genres, such as funk, $M P B^{8}$, forró, Brazilian hip hop, and Brazilian pop. ${ }^{9}$ Figure 3 shows the total streaming of the songs according to their genres. Visualization is seen as a pattern of consumption different from what has been observed so far.

\footnotetext{
${ }^{8}$ Acronym for Brazilian popular music.

${ }^{9}$ Brazilian hip hop is more associated with national rap artists (e.g., Projota) and Brazilian pop singers (e.g., Anitta).
} 


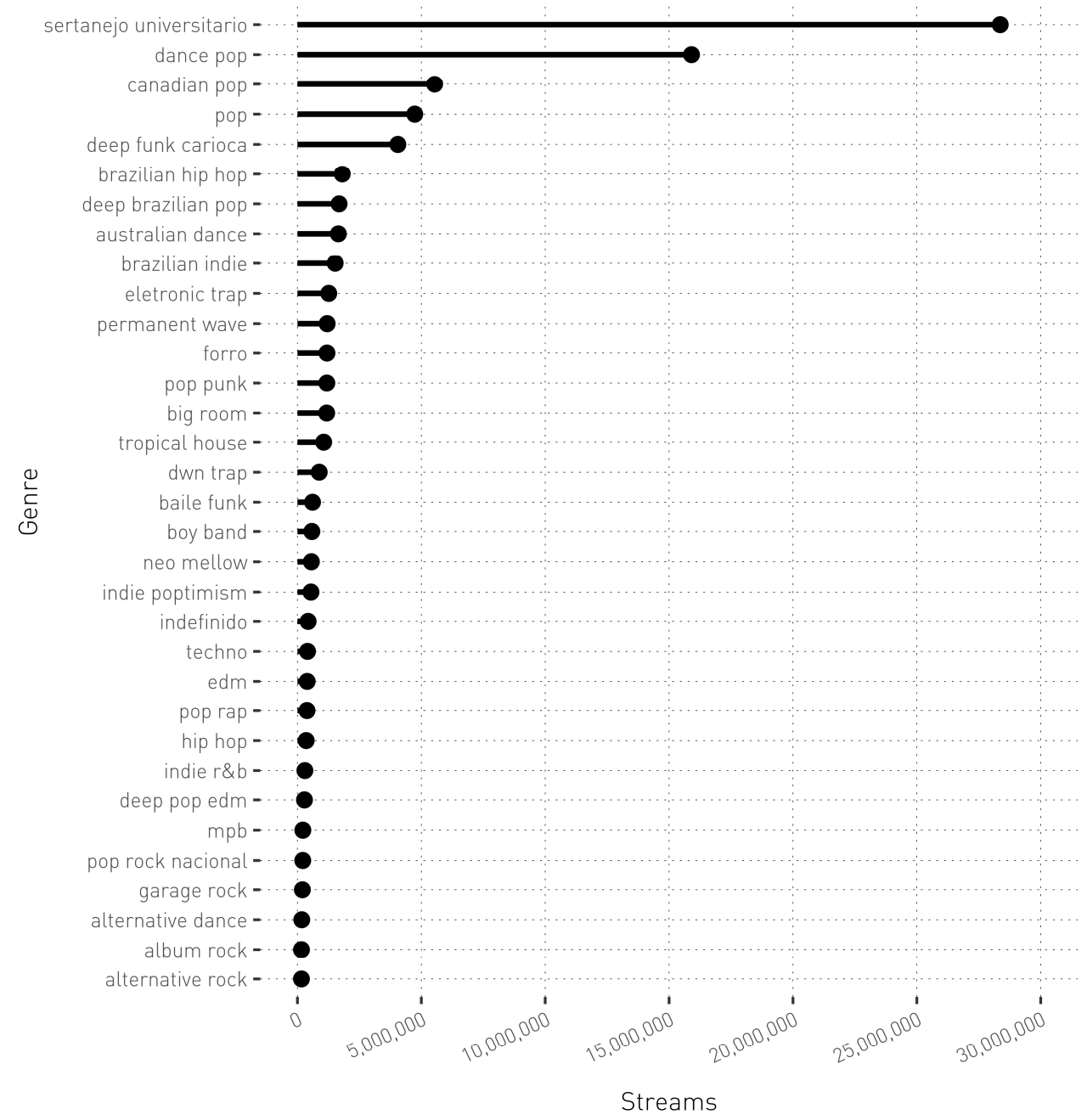

Fig. 3: Total streamings, Brazil, November 2016. Source: SPOTIFY $(2014,2016)$.

Analyzing the number of reproductions, sertanejo universitário was the most reproduced genre in November 2016, followed by the subdivisions of pop. Only after do other national genres appear, like funk, MPB, Brazilian hip hop, and deep Brazilian pop. Associated with the highest number of songs among the 200 most played, the large number of reproductions make sertanejo potentially the most reproduced genre in Brazil. However, analyzing the composition of streaming (Figure 4) in November 2016, a different and curious trend is encountered. 


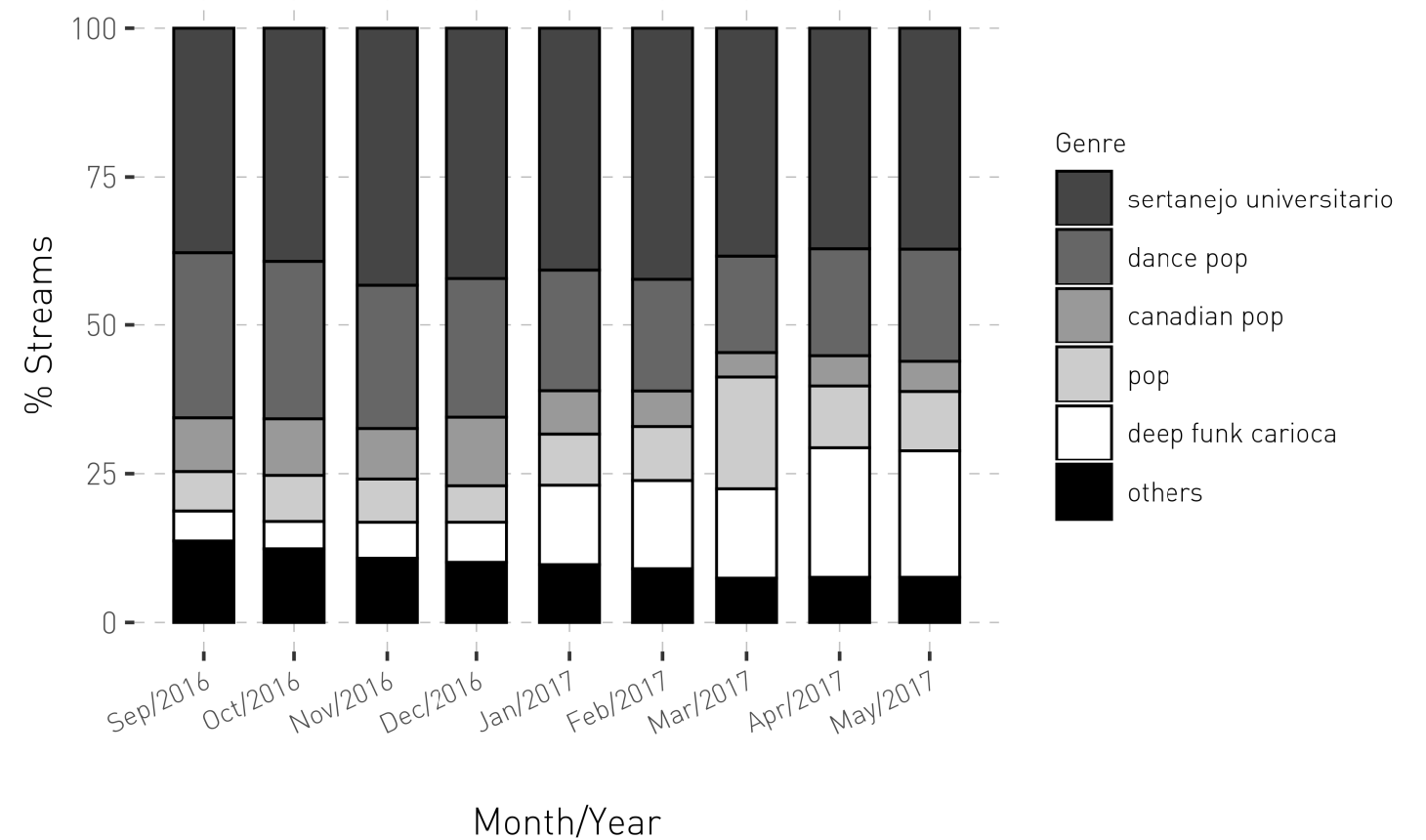

Fig. 4: Streaming ratio, Brazil, September 2016 to May 2017. Source: SPOTIFY $(2014,2016)$.

Graphically, it is noticeable that, from December 2016, there is an expressive ascendancy in the funk streaming volume (deep funk carioca) when compared to other national and international genres. This behavior may be associated with the production company KondZilla, responsible for launching several video clips of "MCs"10 monthly and with wide reach of views on YouTube. The YouTube channel has more than 13 million subscribers and more than 6 billion views (May 2017 figures). The initial

\footnotetext{
10 "MC" is a common acronym used before the name of several artists, mainly of the funk genre.
}

surge occurred between December 2016 and January 2017 with release of the song "Deu Onda" by MC G15. In the first week of January 2017, the song reached more than $3,400,000$ reproductions on Spotify, occupying the first place. Figure 5 shows the evolution of streaming of the national genres with the highest reproductions. 


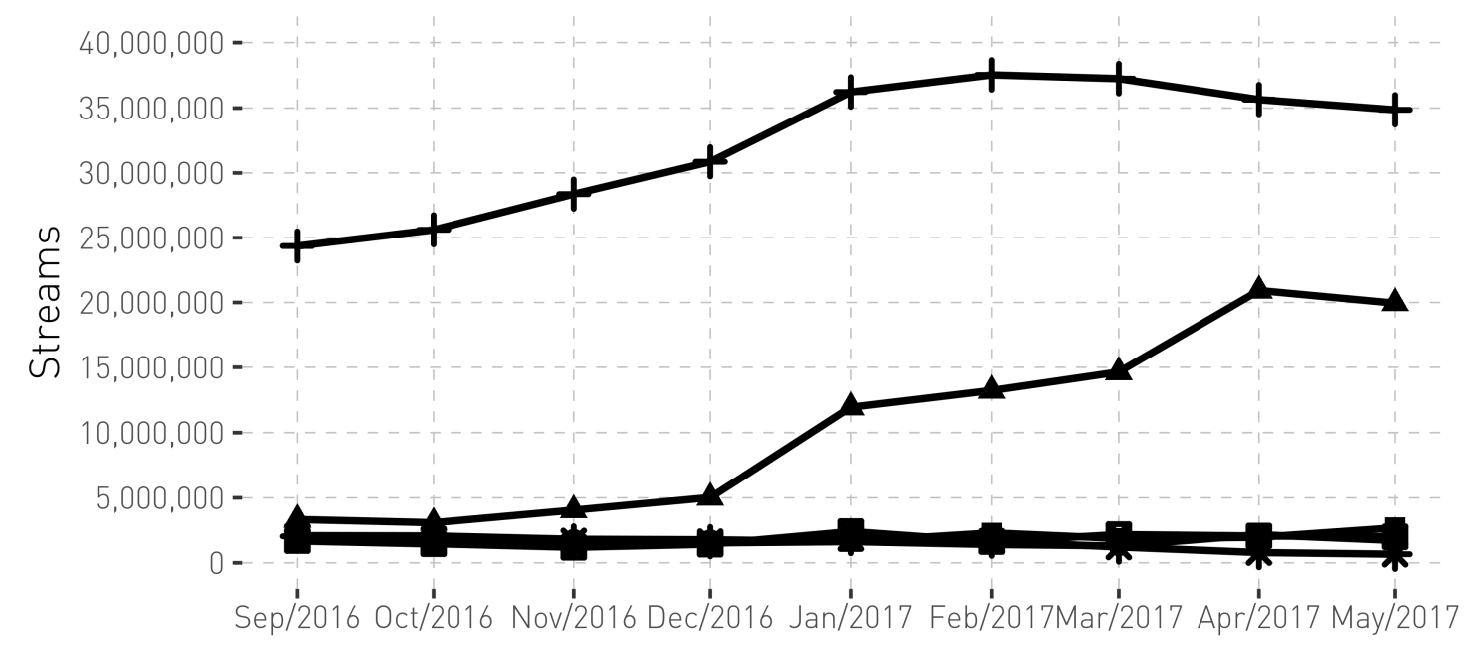

\section{Month/Year}

Genre

- brazilian hip hop - brazilian indie
- deep funk carioca + sertanejo universitario

forro

* deep brazilian pop

Fig. 5: Evolution of streamings, Brazil, September 2016 to May 2017. Source: SPOTIFY $(2014,2016)$.

Except for sertanejo universitário and funk, other national genres show little variation. However, sertanejo had an ascendancy much smaller than that of funk. Between September 2016 and May 2017, the growth of funk-related streamings was approximately $500 \%$, while that of sertanejo was about 43\%. Figure 6 includes the popularity of artists as an analysis variable. In order to better present the information, some genres were aggregated by similarity. 


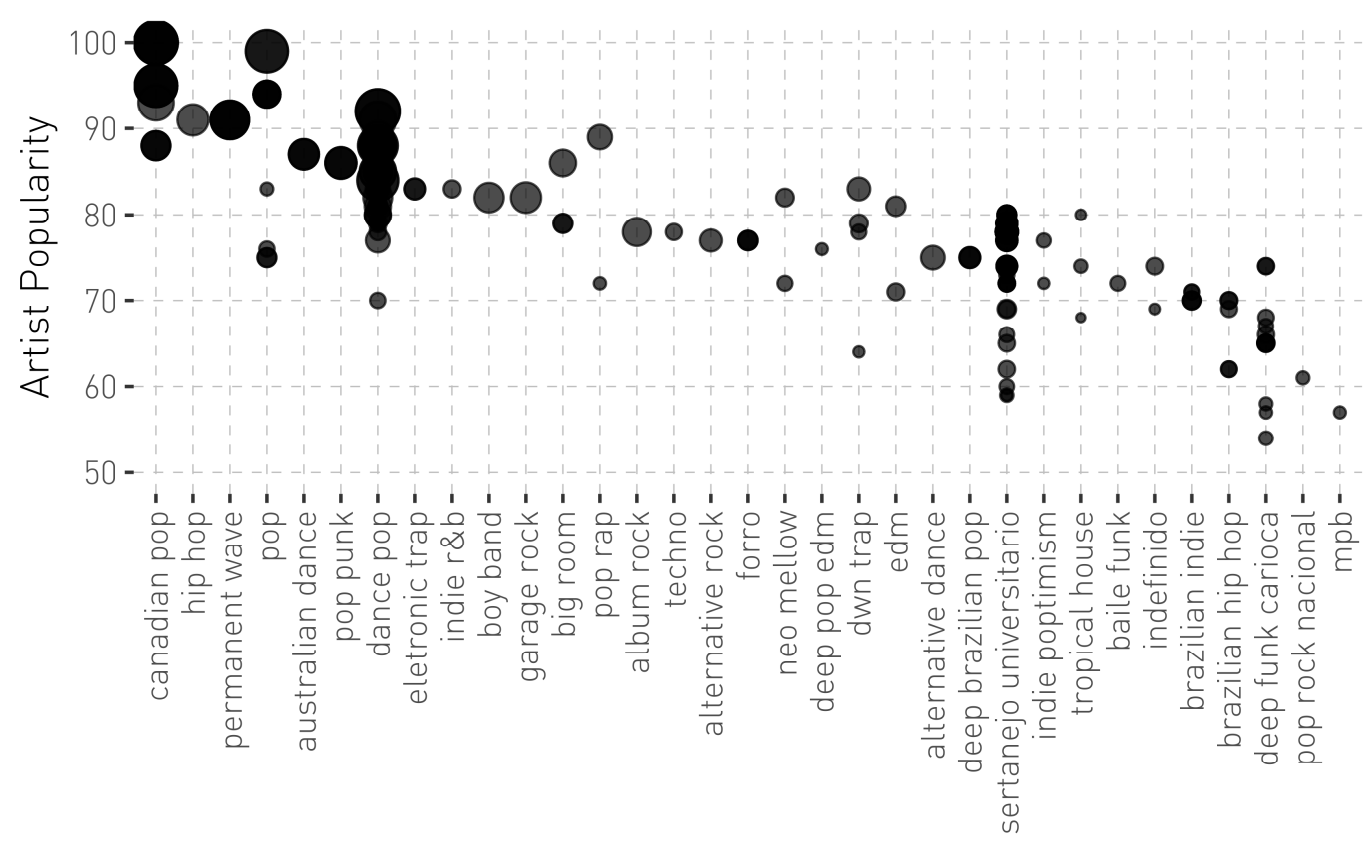

Genre

Followers

Fig. 6: Popularity of Artists, Brazil, November 2016. Source: SPOTIFY $(2014,2016)$.

Again, the dominance of pop and sertanejo is observed, although the most popular artists are international. Other genres stand out for having a high range of popularity of artists, such as sertanejo universitário itself and deepfunk carioca. Such observations may indicate that these genres allow for a greater variety of artists, some more popular than others.

Through the most listened-to songs in Brazil, at the national level, it would be reasonable to assume that Spotify users are predominantly pop listeners, mainly international, sertanejo universitário, and funk, with the first two historically experiencing mass production and greater commercial appeal. The digital platform facilitates the insertion of genres that already have reached traditional media like radio, television, and physical formats. However, the same ease of access can be achieved by artists of other styles and by the evident diversity and cultural production of the country. It is assumed 
that the national level does not reflect digital consumption as a whole.

The descriptive and spatial research of the genres consumed at the local level partly proves this assumption. The most distinctly reproduced songs, or those that stand out locally in the municipalities collected, allow us to better decipher the taste, pattern, and consumption relations of the users in the cities. Many artists and genres exposed by these playlists, on some level, have less reach in the national scene, or as interpreted, are more consumed in their place of origin.

After an initial analysis of the genres, it was observed that some original classifications were sometimes misleading, while others were undefined. It was therefore decided to redefine some of these classifications. ${ }^{11}$ The frequencies of genres of the songs collected in the playlists of the cities confirm a greater reach of the local genres, many of which have not even been observed at

\footnotetext{
${ }^{11}$ In this sense, reclassification is also subject to criticism and misunderstanding. However, again, it is emphasized that, in the diverse environment of music, a fixed framing of genres is a difficult task, and this work does not propose to address such complexity of classifications.
}

the national level. The predominance of sertanejo is still remarkable, since it is heavily consumed in Brazil and very little in cities of other countries. The low frequency of pop, mainly international, is justified by being widely heard in other places in the world, so the algorithm, with exceptions, does not select it as distinct for Brazilian cities.

A first identification of the genres was centered on the playlists of some Brazilian capitals. Figure 7 shows the visual frequency of the genres of the most distinctly consumed music in six capitals. 


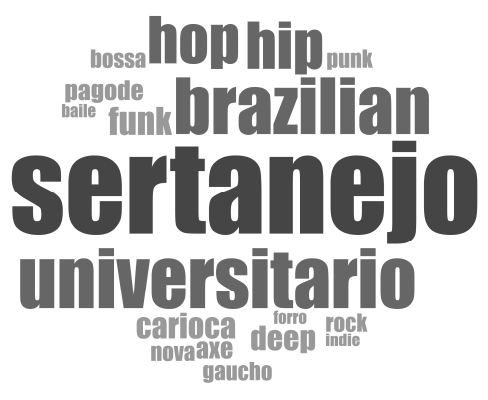

(a) São Paulo (SP)

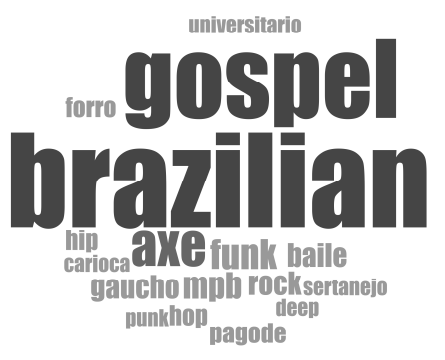

(c) Manaus (AM)

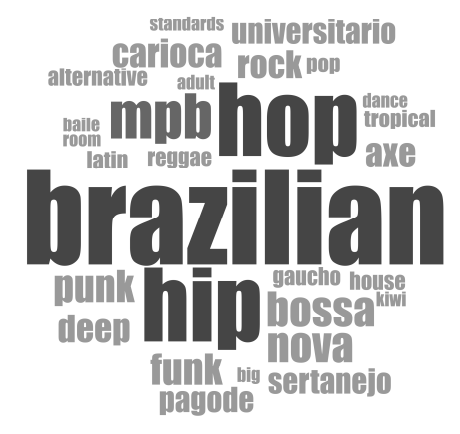

(e) Florianópolis (SC)

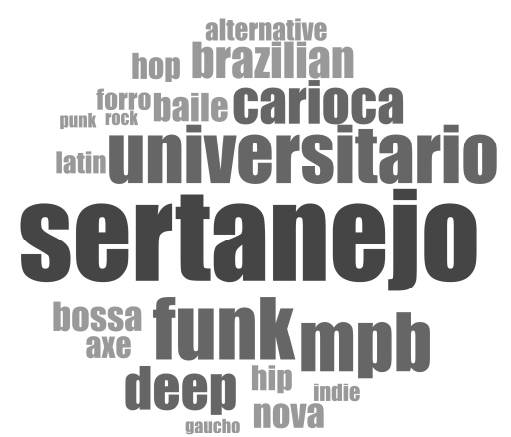

(b) Belo Horizonte (MG)

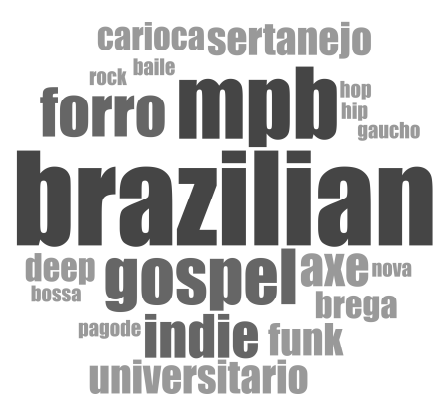

(d) Belém (PA)

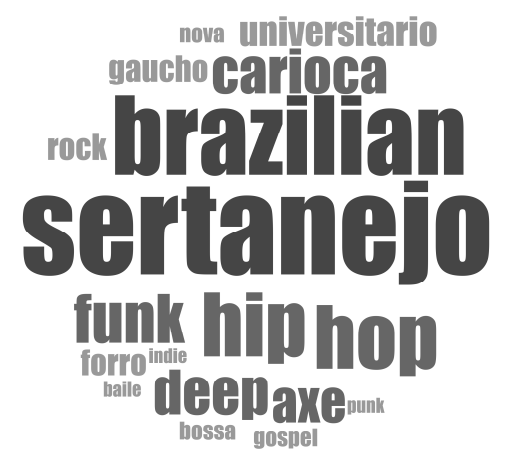

(f) Brasília (DF)

Fig. 7: Genres observed in Brazilian capitals, November 2016. Source: McDONALD (2013); SPOTIFY (2014). 
As observed, there is a pattern of consumption of various musical styles in each of these cities, not just one or two genres. Peterson (1992) refers to individuals who consume various types of cultural goods or activities as omnivores, not restricting themselves to a single taste. City playlists are mere representations of the songs that users listen to in the streaming service. Aguiar and Waldfogel (2015) suggest, through correlation analyses, that Spotify's various rankings are good measures or indicative of their general use. Thus, for the capitals presented, due to the heterogeneity of genres, a possible omnivorous pattern regarding the consumption of music in these cities is indicated.

Besides sertanejo universitário and deep funk in Rio, consumed in the six capitals, other genres stand out. Brazilian hip hop in São Paulo and Florianópolis, Brazilian gospel in Manaus, Brazilian indie in Belém, MPB and pop in Florianópolis, and others are in smaller proportion. Figure 8 presents six other capitals with different consumption patterns from the previous ones.

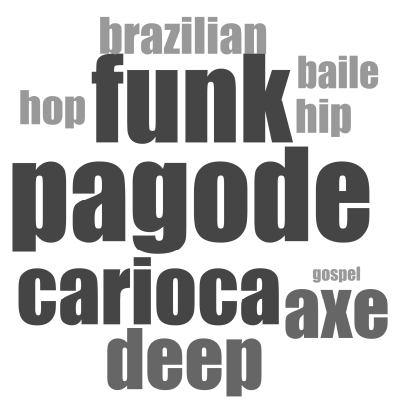

(a) Rio de Janeiro (RJ)

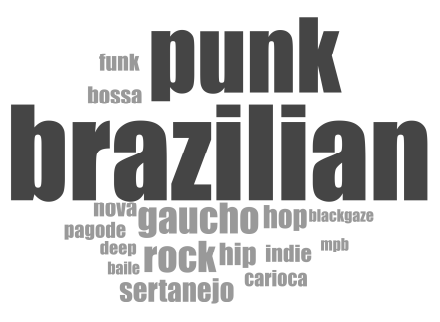

(b) Porto Alegre (RS) 


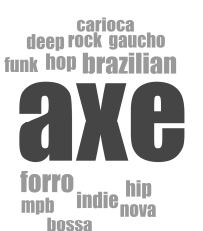

(c) Salvador (BA)

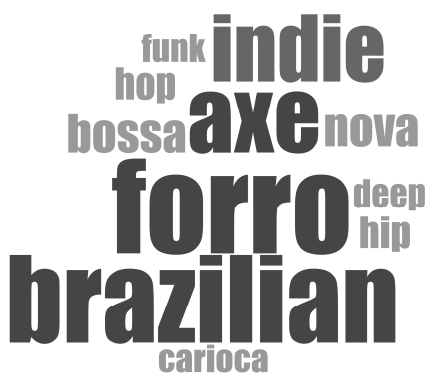

(e) Fortaleza (CE)

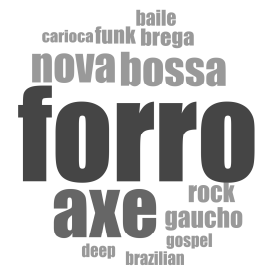

(d) Recife (PE)

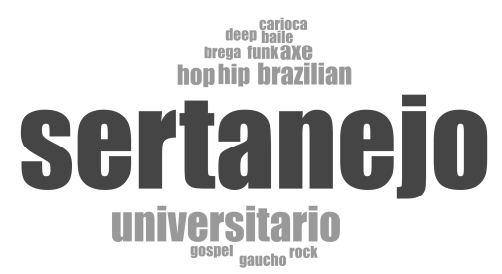

(f) Goiânia (GO)

Fig. 8: Genres observed in Brazilian capitals, November 2016. Source: McDONALD (2013); SPOTIFY (2014).

All the capitals shown in Figure 8 have a specific consumption pattern for certain genres. In some of the capitals, this pattern is more evident, such as nativist and rock music in Porto Alegre, axé in Salvador, forró and brega in Fortaleza, and sertanejouniversitário in Goiânia. In
Rio de Janeiro and Recife, the consumption is divided into a few genres. Recife divides among Brazilian indie, forró, and brega, while Rio de Janeiro is divided among funk, pagode, and Brazilian hip hop. These capitals would typically be classified as univorable consumption patterns, 
according to the propositions of Peterson (1992).

This univorous consumption can be explained by the tradition and history of some genres in these places. In Rio de Janeiro (Figure 8a), for example, as Vicente (2014) points out, the origins of funk refer to the American soul and funk movement of the 1970s and, as in the United States, maintained a strong presence in the black population. The style explodes in the late 1990s with the melody funk phase. In 2001, it rises the phase of batidão and proibidão funk. In the late 2000s, funk was renewed again with the ostentação phase with themes related to the consumption of goods, such as cars and electronic equipment, as a symbol of distinction in the periphery. Similarly, the genres observed in Recife (Figure 8d) establish a direct association with the Mangue Beat. This was an artistic and social movement that emerged in the late 1980s but gained strength in the early 1990s and overcame Recife's barriers. The axé in Salvador (Figure 8c), according to Paulafreitas (2004), dates back to the origins of this style in the 1950s, with the creation of the trio elétrico by Dodô and Osmar, and the afoxé blocks such as Filhos de Gandhi (1949) and llê Ayê (1974). A new Bahian axé scene would come in the late 1980s, accompanied by a new moment in the Brazilian music scene as a whole.

Observed these, we can divide those cities into two groups of consumption patterns. Those of diversified or omnivorous pattern are São Paulo, Belo Horizonte, Manaus, Belém, Florianópolis, and Brasília. Those of univorous consumption or a specific genre are Rio de Janeiro, Recife, Porto Alegre, Salvador, Fortaleza, and Goiânia. Then the analysis expanded to other Brazilian cities and capitals. Figure 9 shows diagrams of the most consumed genres in each Brazilian capital. The data were collected in November $2016 .{ }^{12}$

\footnotetext{
${ }^{12}$ For this month, it was not possible to collect data about capital Campo Grande (MS).
} 


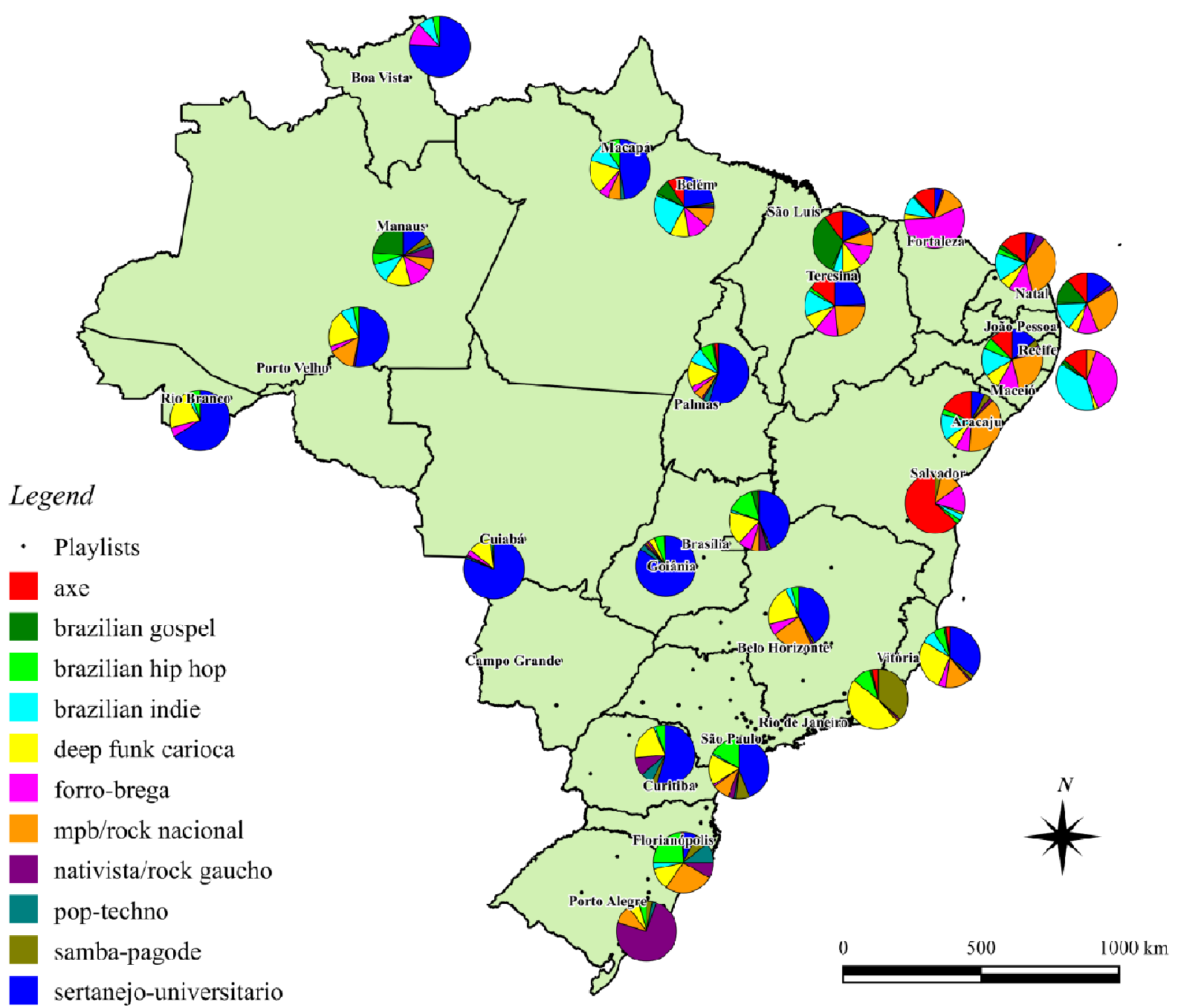

Fig. 9: Consumption by genders, Brazilian capitals, November 2016. Source: McDONALD (2013); SPOTIFY (2014).

There are very different patterns of consumption, and those presented previously are evident. For example, the univorable pattern of capital cities such as Porto Alegre, Rio de Janeiro, Salvador, Recife, Fortaleza, and Goiânia is proven. Like Goiânia, Cuiabá (MT), Rio Branco (AC), and Boa Vista (RR) are intense consumers of sertanejo universitário. Other capitals have a more omnivorous and distributed pattern. In addition to those presented in Figure 8, we can mention Palmas (TO), São Luís (MA), and Maceió ( $\mathrm{AL}$ ). Among other patterns already observed, the following genres are distinguished, in smaller or larger proportions, in the respective capitals: 
- Axé: Salvador;

- Brazilian gospel: Manaus, Belém, São Luís, João Pessoa (PB);

- Brazilian hip hop: São Paulo, Florianópolis, Brasília (DF);

- Brazilian indie: Recife, Belém;

- Deep funk carioca: Rio de Janeiro;

- Forró and brega: Recife, Fortaleza;

- MPB and national rock: Florianópolis, Aracaju (SE), Natal (RN);

- Nativist and rock gaúcho: Porto Alegre;

- Pop and techno: Florianópolis, Curitiba (PR);

- Samba and pagode: Rio de Janeiro;

- Sertanejo universitário: Goiânia, Cuiabá, Rio Branco, Boa Vista.

There are a few capitals where funk and sertanejo do not have a minimum consumption. $M P B$ and national rock also have a welldistributed consumption in the national territory, except perhaps the Midwest region, where the dominion of sertanejo is clear. Forró, besides the capitals of the Northeast region, has reach in Belo Horizonte, Brasília, Manaus, and Belém.

We verified how consumption and tastes present themselves in the other Brazilian cities, including as a way of ascertaining the power of influence of the capitals in the rest of the cities. Figure 10 shows the consumption patterns of all 108 cities collected in November 2016, from 9,302 songs available in playlists in the Every Place at Once domain. 


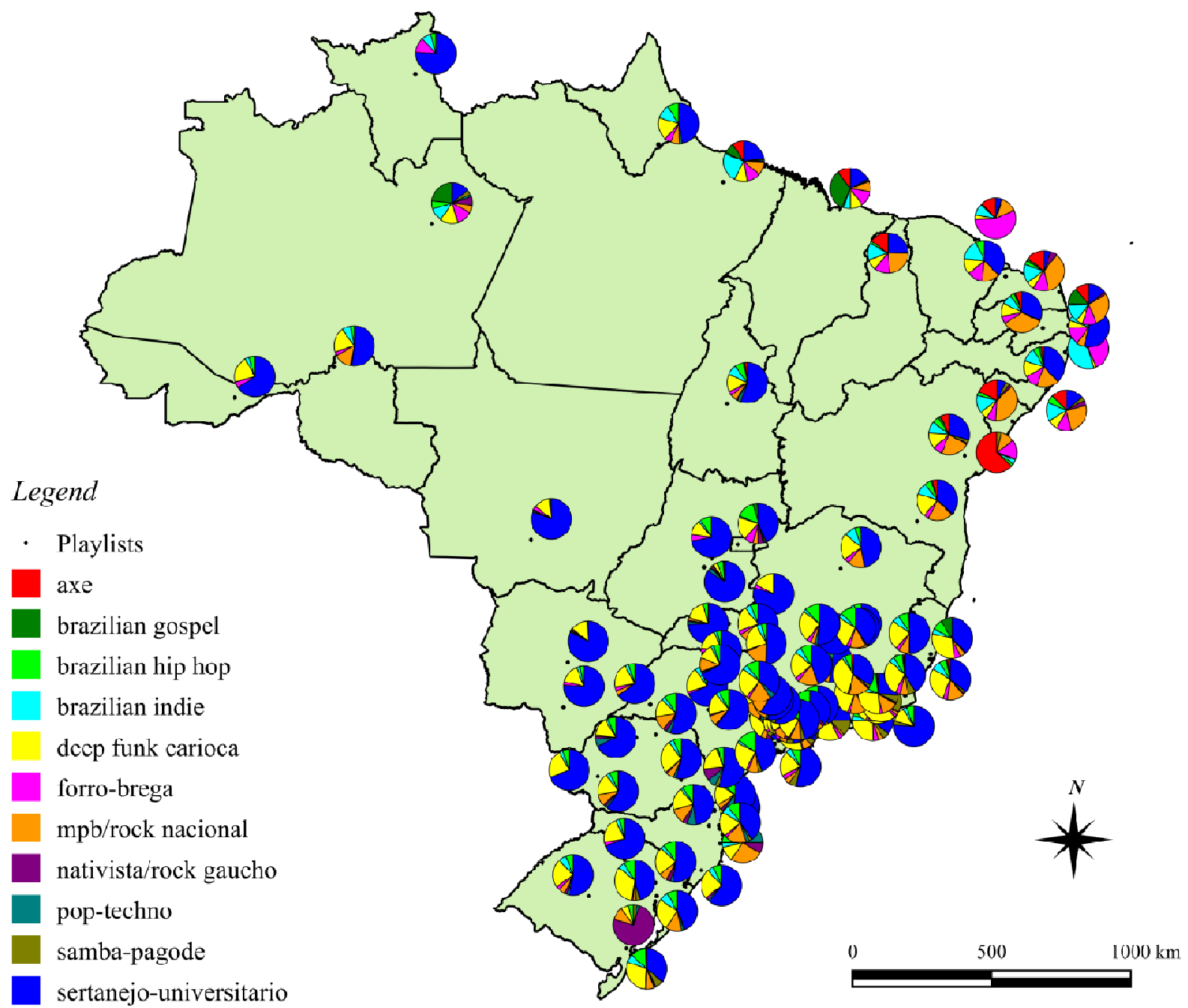

Fig. 10: Consumption by genders, Brazilian cities, November 2016. Source: McDONALD

(2013); SPOTIFY(2014).

In addition to the prevalence of sertanejo, there is a strong proximity and spatial correlation of genders. Among the 108 cities, there are 86 predominate songs from sertanejo universitário, mostly in cities in the South, Southeast, and Midwest, where deep funk carioca also has considerable consumption. In the
South, the capital cities Porto Alegre and Florianópolis are exceptions, and sertanejo does not predominate, as previously shown. In the Southeast, sertanejo has a lower proportion in the cities of the states of Rio de Janeiro and Espírito Santo. In the Northeast and in the largest capitals of the North, its scope is limited. The Northeast 


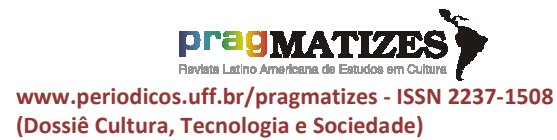

region is where less sertanejo and funk is consumed. In this region, mainly axé, forró, and MPB are consumed.

Brazilian gospel, besides the consumption already highlighted in Manaus, São Luís, and João Pessoa, is also distinguished in some cities of the metropolitan region of the city of Rio de Janeiro, such as São Gonçalo, Duque de Caxias, and Nova Iguaçu, and also in Vila Velha (ES). Samba and pagode, which are predominant in Rio de Janeiro, present relevant consumption also in other cities of the state. On the other hand, music from the state of Rio Grande do Sul (nativist and rock gaúcho) presents a minimum consumption in other cities, but far from the proportion in its capital, Porto Alegre. They are Florianópolis,

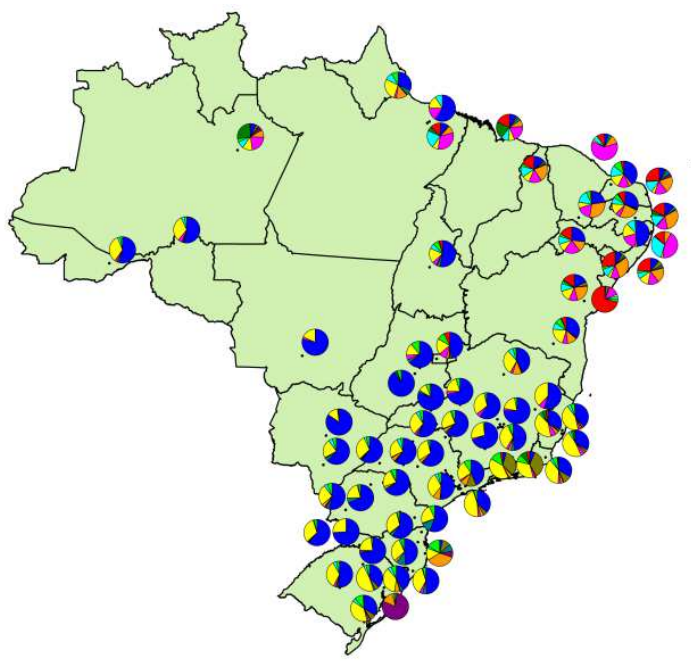

(a) January 2017
Curitiba, Santos (SP), Manaus, and Natal. Likewise, axé has a minimum consumption in practically all the cities of the Northeast, not reaching the same proportion of Salvador.

In order to monitor the evolution of this consumption and to verify that the pattern for November remains, Figure 11 presents consumption patterns for the months of January, March, and May 2017. A total of 115, 84, and 106 playlists were collected from cities for each month, respectively, totaling 9,530, 7,607, and 9,954 songs. The months were interspersed in order to obtain greater variability of the playlists. For better visualization, some cities were omitted without affecting the analysis, given a similar spatial pattern.

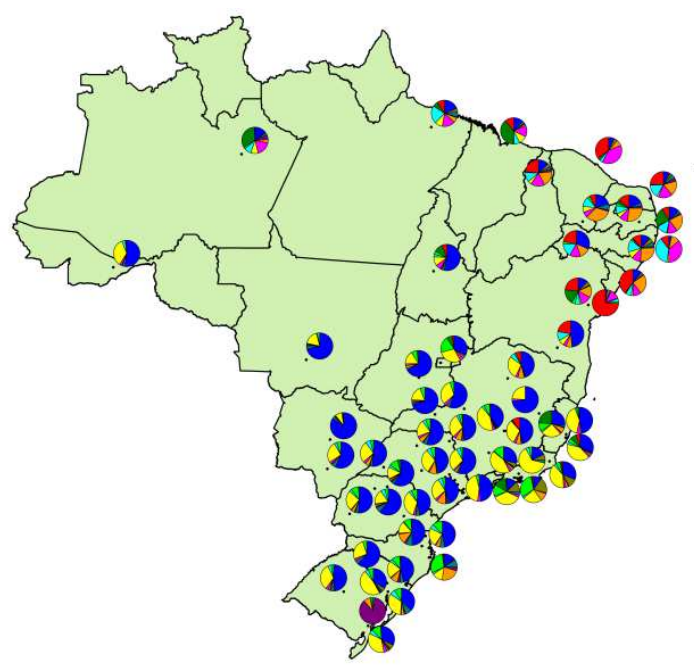

(b) March 2017 


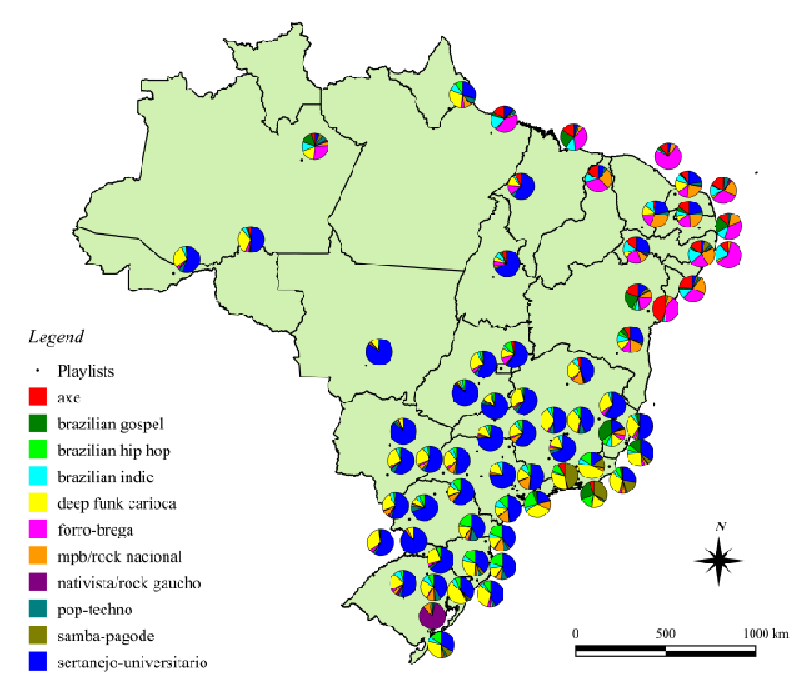

(c) May 2017

Fig. 11: Evolution of consumption by gender, Brazilian cities. Source: McDONALD (2013); SPOTIFY (2014).

Most genres maintain their spatial reference. However, some changes are noteworthy. An expansion of funk is confirmed, especially if we observe the maps of January and March of 2017. In March, samba and pagode lost space to other genres in the state of Rio de Janeiro. In relation to axé, there was an increase in consumption in the Northeast. In addition to Salvador, increased consumption was found mainly in Aracaju, Fortaleza, Feira de Santana (BA), and Vitória da Conquista (BA). In May, however, this consumption contracted, when there was an increase in the proportion of forró and brega in the cities of the Northeast. Focusing on Salvador, it is possible to see this expansion; axé reduced its market share, practically dividing consumption with forró and brega. In Fortaleza, the consumption of this genre reached a univorous level similar to the consumption of sertanejo in other cities, such as Goiânia and Cuiabá. In the same month, there was also an increase in consumption of Brazilian hip hop music, particularly in the Southeast and South regions. Samba and pagode regained consumption levels in the cities of the state of Rio de Janeiro that they obtained in November 2016 and 


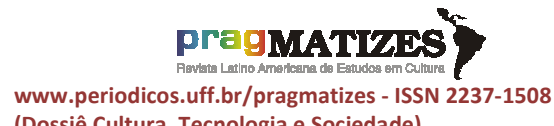

(Dossiê Cultura, Tecnologia e Sociedade)
January 2017. Pop and techno also showed a small increase in consumption over the months.

In this range, it is also worth mentioning the expansion of Brazilian gospel in some places. Presence is maintained in Manaus, São Luís, and João Pessoa, while increasing consumption in the cities already mentioned in the metropolitan region of Rio de Janeiro, including Belford Roxo and São João do Meriti, and in the cities of Espírito Santo, such as Vitória, Serra, and Vila Velha. In the cities of the metropolitan region of Rio de Janeiro, gospel divides the consumption, mainly with funk, samba, and pagode. In the capital, however, the consumption of gospel is inexpressive. There are also increases in other cities, such as Feira de Santana (BA), Campina Grande (PE), Palmas, Belém, and Brasília.

The analysis by the Brazilian territory confirms that there are close relationships of some genres with the cultural identity of the cities where they are consumed, while others seem to be associated with mass production processes and greater market emphasis. More obvious examples of the first situation would be cities with extremely univorious consumption patterns in one or two genders. The second situation could include those cities where, even considering the most distinctly consumed songs, the consumption of sertanejo universitário is still significant, sharing space with other genres, often MPB and deep funk carioca. According to Junior (2008, p. 40):

It is possible to notice a relation between the musical label and a supposed taste of the listener (...). In virtual terms, the genres and their settings in the songs describe not only who the consumers are, but also the possibilities of meaning of a certain type of music for a particular audience. In the labeling there is a certain way of sharing experience and musical knowledge. (authors' translation)

As Paulafreitas (2004) notes, especially in the last decade, the phonographic market generally underwent restructuring and segmentation. The digital music consumption described by Spotify's playlists features both traditional and mass-replacement models. This would be represented by the genres typically with greater marketing appeal, such as 
sertanejo universitário and, more recently, funk.

In the same way that Anderson (2006) advocates for other services and segments, it is possible to say that there is a "Spotify Long Tail" where local genres and artists or those with less popularity than the "big stars" can be heard. Figure 12 demonstrates this assumption. There were 920 artists collected in the playlists of Brazil and the cities between November 2016 and March 2017. The distribution of the first characterizes exactly the decay of the Power Law, the same observed for other phenomena of "Long Tail", where few items are consumed in high volume and most are consumed in small volumes, but which together represent a significant portion (PARK et al., 2007).

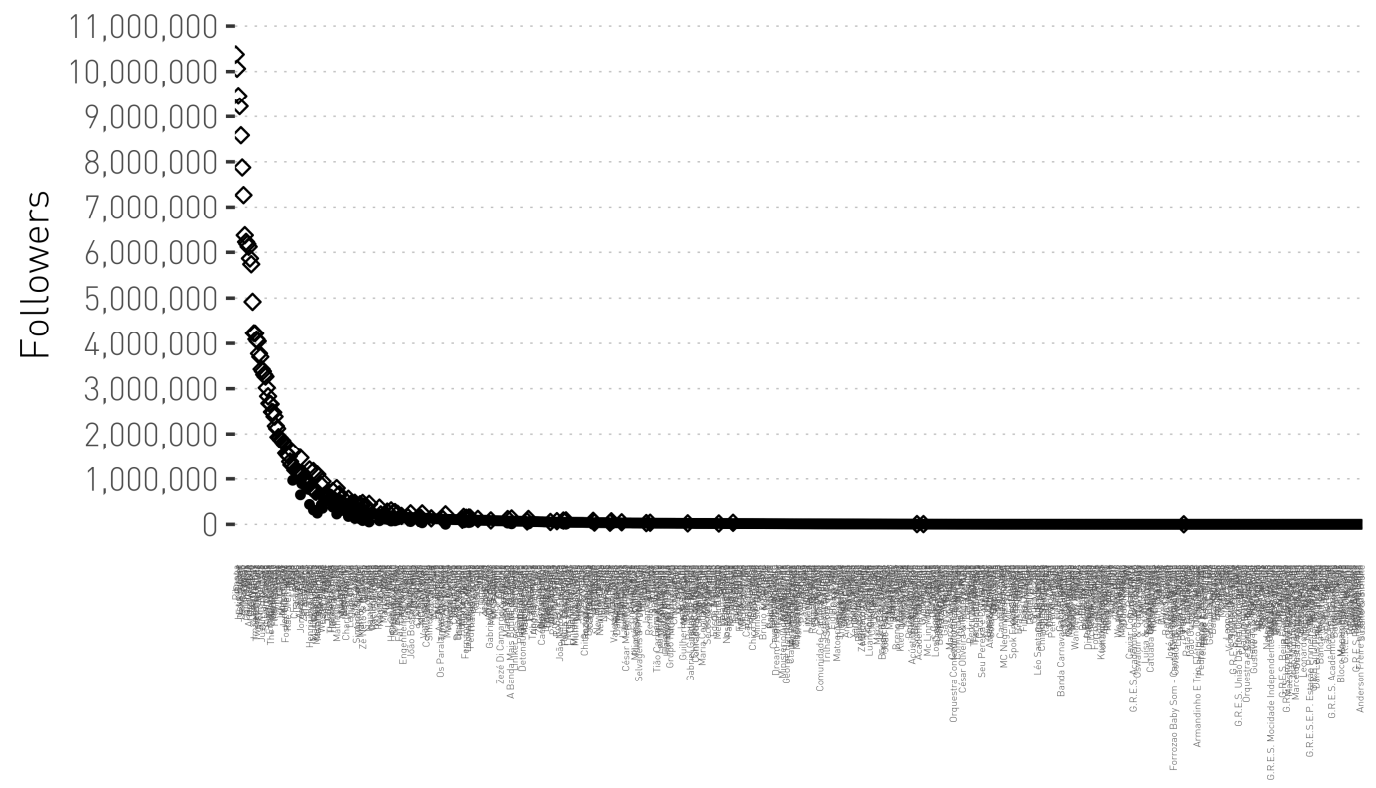

Artist

Artist of: • Local (Cities) Playlists $\diamond$ National Playlists

(a) Artists' Followers 

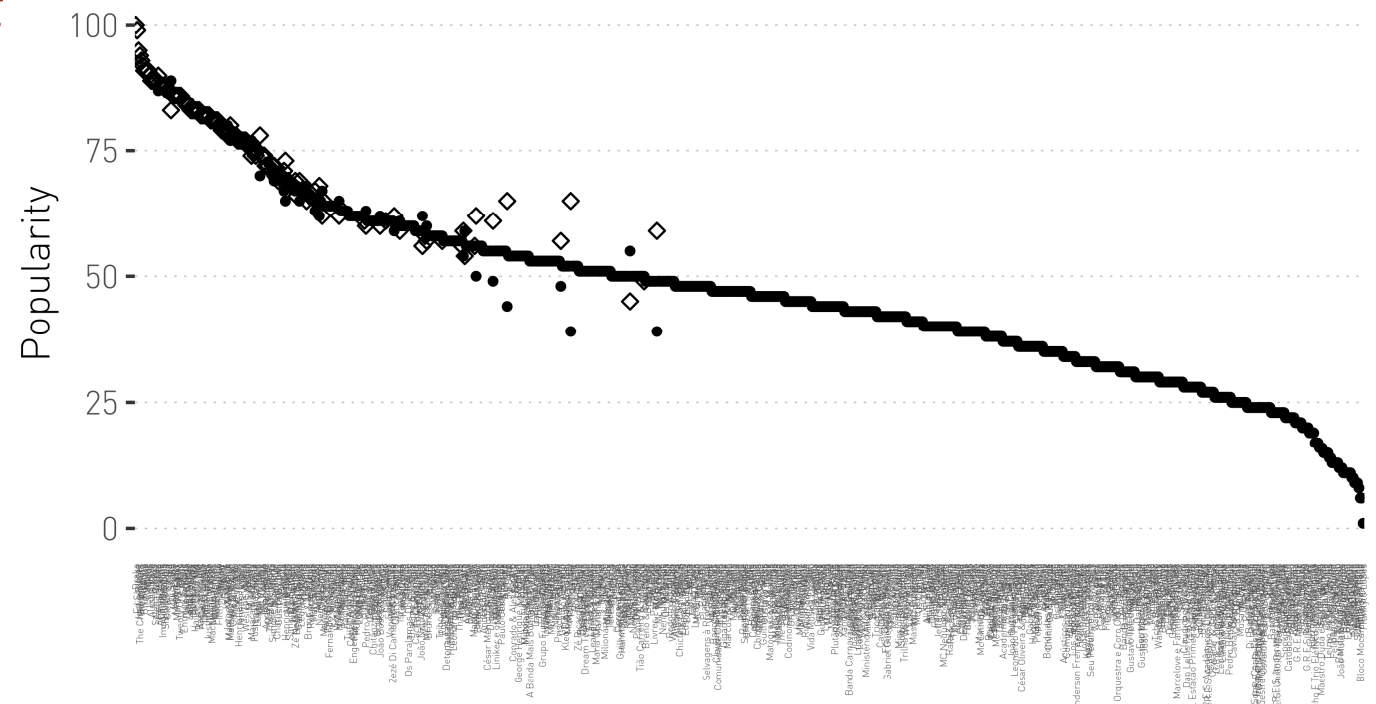

Artist

Artista of: • Local (Cities) Playlists $\diamond$ National Playlists

(b) Artists' Popularity

Fig. 12: Long Tail of streaming music. Source: McDONALD (2013); SPOTIFY $(2014,2016)$.

Most of the artists present in the national playlists refer to the international pop genres or the great stars of sertanejo universitário and national pop. These occupy the top positions in relation to both the followers and popularity, and, as Anderson (2006) affirms, those are the great successes that always had space in the physical market. However, the curve shows a large number of artists with followers below 1.5 million, most of whose songs are on local playlists, a grouping that Anderson (2006) calls "non-hits."
Therefore, it is possible that streaming services will be an effective tool and drive an effective demand of less popular genres and artists, to the point where this "non-hits" market rivals that of hits. The recommendations, playlists, stations, and other resources available in the application would be facilitators - the "link between supply and demand and even possible 'hits'and niche guides." As pointed out by Peltier et al. (2015), the simultaneous consumption of "hits" and "non-hits" is possible in the digital markets due to search 


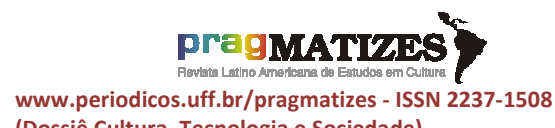

(Dossiê Cultura, Tecnologia e Sociedade) engines and recommendation services.

Thus, we would initially imagine that sertanejo universitário would predominate in the whole of Brazil; however, it is observed that the genres of market niches also have a relevant local appreciation when inserted in the digital service.

\section{Final remarks}

We believe that this work contributes to a better understanding and dimension of music consumption in Brazil. Particularly regarding innovations in the phonographic sector and the advancement of streaming platforms, the analysis of this consumption from data from Spotify reveals crucial results and suggests questions for future research. The first concerns democratization and reduced costs of access to music. Currently, with Internet access, a music listener can listen to an extensive list of genres and artists, free of charge, through digital platforms. Also, for a monetary value, sometimes less than the purchase of a single CD, it is possible to purchase monthly subscriptions for streaming music services, such as Spotify.
The possibility of constructing robust indicators with the data provided by the Spotify API (Spotify Web API) is a proposed methodological advance. Access to these types of data or any data from digital platforms guarantees the elaboration of a diverse range of indicators at a low cost and with sample representativeness only verified in census collections, recognized by their high price and, therefore, with periodicity in most countries. Thus, in the field of the culture economy, where changes have occurred in a vertiginous way due to the digitization process, and where there is no scope or periodicity in the construction of secondary databases, access to APIs has become an essential and alternative data tool.

The observation of almost realtime consumption helps to follow trends and their evolution according to musical styles. As an example, there was a relatively significant consumption of gospel style in some cities. There was also a substantial rise in funk consumption at the national level, but mainly in the South and Southeast regions. This may reveal a shift from the segment industry to a mass market profile. 
Finally, it is emphasized that dimensioning, describing, and mapping culture and cultural goods are arduous tasks for both the symbolic and immeasurable value of the object in question. Particularly regarding music, at no time was it intended to value or devalue specific genres or artists. On the contrary, in the diversity of the territorial and cultural extension of Brazil, every manifestation, at the micro, local, regional, and national levels, is valued. It is believed that dimensioning art is a way of strengthening cultural identities, thinking of ways of encouraging, perpetuating, and evaluating them.

Acknowledgements: We thank all Spotify Web API, Python, R, QGIS, Beautiful Soup, ggplot2 and wordcloud (R Core Team 2018; QGIS Development Team 2009; Richardson 2017; Wickham 2016; Fellows 2014) contributors which made possible this work.

\section{References:}

AGUIAR, L.; WALDFOGEL, J. Even the losers get lucky sometimes: New products and the evolution of music quality since Napster. Information Economics and Policy, Elsevier, v. 34, p. 1-15, 2016.

AGUIAR, L.; WALDFOGEL, J. Streaming Reaches Flood Stage: Does Spotify Stimulate or Depress Music Sales? NBER Working Paper, (w21653). Available at SSRN: https://ssrn.com/abstract=2679691. 2015.

ANDERSON, C. A Cauda Longa. Rio de Janeiro: Elsevier Brasil, 2006.

CAVES, R. E. Organization of arts and entertainment industries. Handbook of the Economics of Art and Culture, Elsevier, Amsterdã, v. 1, p. 533-566, 2006.

COULANGEON, P.; LEMEL, Y. Is "distinction" really outdated? Questioning the meaning of the omnivorization of musical taste in contemporary France. Poetics, Elsevier, v. 35, n. 2, p. 93-111, 2007.

CVETKOVSKI, T. The Political Economy of the Music Industry: Its Rise and Stall. In: Australasian Political Studies Association Conference. Adelaide: University of Adelaide, 2004. FELLOWS, I. wordcloud: Word Clouds. R package version 2.5. 2014.

LEYSHON, A. Reformatted: Code, Networks, and the Transformation of the Music Industry. Oxford: Oxford University Press, 2014.

LIEBOWITZ, S. J. How much of the decline in sound recording sales is due to file-sharing? Journal of Cultural Economics, Springer, v. 40, n. 1, p. 13-28, 2014.

LIEBOWITZ, S. J. Will MP3 Downloads Annihilate the Record Industry? The Evidence so Far. In: LIBECAP, G. (ed.). Intellectual Property and Entrepreneurship. Emerald Group Publishing Limited, 2004. p. 229-260.

MCDONALD, G. Every Place at Once. 2013.

http://everynoise.com/everyplace.cgi. Accessed 28 August 2018.

OBERHOLZER-GEE, F.; STRUMPF, $K$. The effect of file sharing on record 
sales: An empirical analysis. Journal of Political Economy, The University of Chicago Press, v. 115, n. 1, p. 1-42, 2007.

PARK, J.; CELMA, O.; KOPPENBERGER, M., CANO, P., BULDÚ, J. M. The social network of contemporary popular musicians. International Journal of Bifurcation and Chaos, World Scientific, v. 17, n. 07, p. 2281-2288, 2007.

PAULAFREITAS, A. Música de rua de Salvador: preparando a cena para a axé music. In: CULT. I ENECULT Encontro de Estudos Multidisciplinares em Cultura. Salvador, 2004.

PELTIER, S.; BENHAMOU, F.; TOURÉ, M. Does the long tail really favor small publishers? Journal of Cultural Economics, Springer, p. 1-20, 2015.

PETERSON, R. A. Understanding audience segmentation: From elite and mass to omnivore and univore. Poetics, Elsevier, v. 21, n. 4, p. 243258, 1992.

POTTS, J. New technologies and cultural consumption. In: GINSBURGH, V. A.; THROSBY, D. (ed.). Handbook of the Economics of Art and Culture. 2. ed. Amsterdam: Elsevier, 2014. p. 215-231.

PREY, R. Now Playing. You: Big Data and the Production of Music Streaming Space. Doctoral dissertation. Communication, Art \& Technology: School of Communication. Simon Fraser University, 2015.

PRÓ-MÚSICA BRASIL, P. F. A. Mercado Fonográfico Mundial e
Brasileiro em 2016: Relatório Anual Eletrônico Pró-Música Brasil. 2017. https://promusicabr.org.br/home/numeros-domercado/. Accessed 17 September 2018.

QGIS Development Team. QGIS Geographic Information System. Open Source Geospatial Foundation, 2009.

R Core Team. R: A Language and Environment for Statistical Computing. R Foundation for Statistical Computing, Vienna, Austria, 2018.

RICHARDSON, L. Beautiful Soup Documentation, 2017. https://buildmedia.readthedocs.org/me $\mathrm{dia} /$ pdf/beautiful-soup-

4/latest/beautiful-soup-4.pdf. Release 4.4.0. Accessed 28 November 2018.

SPOTIFY. Spotify Charts, 2016. https://spotifycharts.com/regional.

Accessed 28 August 2018.

SPOTIFY. Spotify Web API, 2014. b API. https://developer.spotify.com/webapi/. Accessed 28 August 2018.

THROSBY, D. The Music Industry in the New Millennium: Global and local perspectives. Global Alliance for Cultural Diversity, UNESCO Division of Arts and Cultural Enterprise, 2002.

VAZ DE MELO, Gabriel Borges. O Som do Spotify BR: dimensões do consumo de música digital no Brasil. (Mestrado em Economia). Centro de Desenvolvimento e Planejamento Regional, Universidade Federal de Minas Gerais, Belo Horizonte, 2017.

WICKHAM, H. ggplot2: Elegant Graphics for Data Analysis. SpringerVerlag New York, 2016. 